RESEARCH ARTICLE

\title{
THE HANDLING OF CRIMINAL ACT OF THEFT WITH VIOLENCE BY CHILDREN OF THE DIRECTORATE OF CRIMINAL INVESTIGATION OF THE CENTRAL JAVA REGIONAL POLICE
}

\author{
Dhara Ayu Restuning Tyas ${ }^{1 \bowtie}$, Rodiyah ${ }^{2}$ \\ ${ }^{1}$ Directorate of General Criminal Investigation, Central Java Regional Police \\ Department, Semarang, Indonesia \\ ${ }^{2}$ Faculty of Law, Universitas Negeri Semarang, Indonesia \\ $\triangle$ dharaayutyas@gmail.com
}

\section{CITED AS}

Tyas, D.A.R., \& Rodiyah, R. (2020). The Handling of Criminal Act of Theft with Violence by Children of the Directorate of Criminal Investigation of the Central Java Regional Police. Journal of Law and Legal Reform, 1(2), 273-278. DOI: https://doi.org/10.15294/jllr.vlil.35451

\section{ABSTRACT}

The crime of theft with violence is one of the most frequent crimes or criminal acts in the community. It almost happens in every region in Indonesia. They have the tendency to steal when the opportunity is present, then the perpetrators do it with no regard for time. However, in some cases, the theft is done in a certain time. It involves a condition where everyone will look for the right time to carry out their operations. It appears that in fact, we want to realize a handling of child cases. This handling has to pay attention to the needs of children, so that children affected by criminal cases are not harmed physically or mentally. The barriers experienced in law enforcement carried out by children include, legal regulations themselves, facilities and infrastructure, society, and culture.

Keywords: Criminal Acts, Theft with Violence, Children. 


\section{TABLE OF CONTENTS}

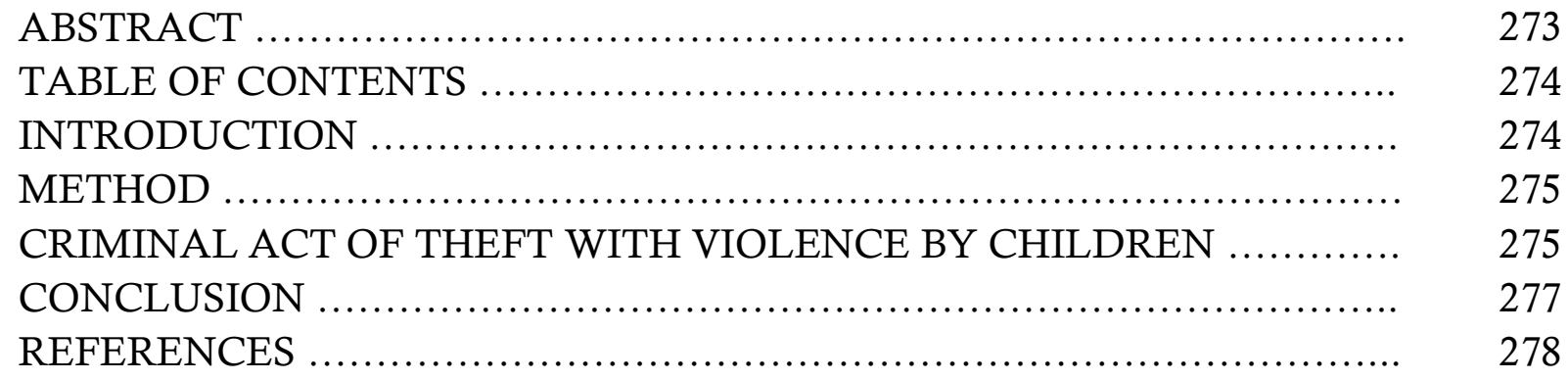

\section{INTRODUCTION}

Crimes could happen anytime and anywhere. The violation is not only committed on men and women, but also on children. Nowadays, people always compete to get the best. If they do not get what they want, they will do everything to achieve their goals, including committing a crime. The crime is committed because of several factors including, the initial environment, heredity, socio-economic status, current living conditions, crises, and negative events. They commit crimes not only as a necessity of life, but also because of the ongoing time.

The crime of theft with violence is one of the most frequent crimes or criminal acts in the community. It almost happens in every region in Indonesia. The tendency of theft happens when the opportunity is present. Then, the perpetrators do it with no regard for time. In some cases, the theft is carried out within a certain time. It involves a condition where everyone will look for the right time to carry out an operation. In the occurrence of a criminal act, there are two parties involved in it, the perpetrator and the victim.

According to Widiartana (2014: 4), in 1937, Benjamin Mendelsohn conducted a research on the victim's personality. Compared with the study of crime which at that time was mostly done and was offender oriented, the study conducted by Mendelsohn could be said to be a new breakthrough because with his research, Mendelsohn tried to explain the criminal act seen from the perspective of the victim.

Actually, the problem of victims is not new. In general, it can be said that there is no crime without victims, although there are also some crimes without victims. Even though there are also some crimes that occur without victims, in the sense that the victims of the crime are also the perpetrators themselves. For example, gambling and drug abuse in criminal law can be said to be criminal if the consequences of such actions cause a victim or have the potential to cause a victim.

According to Gosita (2018), victimology is a study that examines the problem of victims, the victim's victims, and the consequences of victims in studying crime. Usually, people only pay attention to the components of the perpetrators, the law, and law enforcement officers. Even if the victim factor is questioned, the study is not 
carried out comprehensively and thoroughly. Frequently asked questions in the study of crime are usually why a person commits a crime, what are the causes, how the actions of law enforcement officers in dealing with crime and so on. However, the role of victim access in crime is often forgotten.

A crime, in general, must involve two parties, the perpetrator of crime and the victim. A crime is very likely to occur precisely because of the role of the victim, such as the attitude, behavior, and lifestyle of the potential victims. It often provides stimulation to the perpetrators to carry out his evil intentions. Thus, the occurrence of the crime is not an absolute mistake of the perpetrators. However, the existence of such facts is not or less in gaining attention in the legal rules and people's views about crime.

\section{METHOD}

This study uses qualitative methods. Qualitative research is a research that intends to understand the phenomena about what is experienced by the research informants such as behavior, perception, motivation, actions, etc. holistically and by means of descriptions in the form of words and language, on a special natural context and by utilizing various natural methods (Moleong, 2013: 6).

This type of research uses empirical juridical which in other words is a type of sociological legal research and can also be referred to as field research. The research location uses in this study is the Central Java Regional Police. The focus in this study is the perpetrators of crime in the theft and investigators of the Central Java Regional Police. The main data sources in qualitative research are words and actions, and the rest are additional data (Lofland in Moleong 1988: 112). The data source in this study is the informant. The informant in this study is the Central Java Regional Police investigation team. The respondents referred to in this study are the teams involved in the problem of criminal acts of theft with violence (investigator or police). The data analysis techniques used is an interactive model that is done by means of data collection, data reduction, data presentation, and data verification (Miles and Huberman in Rachman, 2012: 200-201).

\section{CRIMINAL ACT OF THEFT WITH VIOLENCE BY CHILDREN}

The essence and meaning of law enforcement lies in the activities of creating and maintaining the peace of association of life. The success of law enforcement may be influenced by several factors that have a neutral meaning, so that the negative or positive impact lies in the contents of these factors. These factors have a closely related relationship, which is the essence and benchmark of the effectiveness of law enforcement. These factors are law (constitution), law enforcement, facilities, society, and culture. It causes theft with violence in the jurisdiction of the Central Java Regional Police. Economic factor is a result of the occurrence of theft in the 
jurisdiction of the Central Java Regional Police. It is based on the results of the study done by the researcher of the respondents of General Investigation Criminal Investigators. These economic factors also occur due to their low level of education. They do not have special skills or expertise to be able to compete in society to find a decent job with sufficient income to meet their needs.

In the perspective of the environmental factors, the perpetrators of theft in the jurisdiction of the Central Java Regional Police have an average basis of faith that is lacking. Since childhood, they are not equipped with the correct religious teachings by their parents. Those who were not equipped with religious teachings from childhood are also caused by their birth from broken families, and the weak selfdefense of the perpetrators in adjusting themselves in their social relations and the existence of social jealousy in their environment. The rich get richer, and the poor get poorer.

The politics of criminal law (criminal law policy) is one of the efforts in overcoming crime, in rational enforcement of criminal law. The rational criminal law enforcement consists of three stages, the formulation stage, the application stage, and the execution stage.

1. Formulation stage is the stage of criminal law enforcement (in abstracto) by the legislative. In this stage, the legislator conducts activities to choose values that are in accordance with the present and future circumstances and situation. Then, they formulate it in the form of regulations in criminal legislation to achieve the best criminal law results in the sense of meeting the requirements of justice and effectiveness. This stage can also be called as the legislative policy stage.

2. Application stage is the stage of criminal law enforcement (the stage of applying criminal law) by law enforcement officials starting from the police, the attorney's office to the court. At this stage, the law enforcers enforce and apply criminal legislation that has been made by the legislative. In carrying out this task, law enforcement officials must uphold the values of justice and usability. This second stage can also be called as the judicial policy stage.

3. Execution stage is the concrete enforcement stage (implementation) of criminal law by the criminal implementing apparatus. In this stage the criminal implementation apparatus has the duty to enforce the criminal rules that have been made by the legislators through the application of the criminal law determined by the court. The implementing apparatus in carrying out their duties must be guided by the criminal legislation that has been made by the legislators and the values of justice and usability.

The three stages of criminal law enforcement, seen as a rational effort or process that is deliberately planned to achieve certain goals. Clearly, it must be an unbroken chain of activities that is rooted in values and leads to crime and punishment.

Violent theft crimes often occur in the environment around us. Therefore, the way to deal with these crimes varies and is adapted to the circumstances in a community. The culture, the government, and its policies also influence the ways of overcoming the crime of theft with violence, to overcome these crimes it is necessary to have an effort or prevention, including preemptive efforts. Here are the initial 
efforts made by the police to prevent criminal acts. These efforts are to instill these values internalized in a person. The target to be achieved is the creation of awareness, alertness, deterrent power and the establishment, and creation of a condition of behavior and norms of life that is free from negative behavior. This activity is basically in the form of fostering and developing a community's lifestyle. The method carried out by the police institution is to provide counseling on the impact caused by the penetrator for himself as well as for his family and future as citizens. Efforts are made to prevent the occurrence of violent crime through the control and supervision of official channels as well as direct supervision of illicit trafficking routes so that the potential for such crimes does not develop into factual threats.

The preventive efforts (prevention) is the prevention efforts carried out systematically, planned, integrated and directed with the aim that the perpetrators of theft crimes with violence do not arise. These preventive efforts are a follow-up of preemptive efforts which are still in the level of prevention before the occurrence of crime. This prevention effort also carries actions that narrow the space for movement. These countermeasures are carried out systematically, planned, integrated and directed, good cooperation is needed in this case and the community.

\section{CONCLUSION}

The factors causing the occurrence of theft crimes by violence committed by children in the jurisdictions of Central Java Regional Police are caused by 3 main factors, namely economic factors, environmental factors of perpetrators and law enforcement factors. In addition to these 3 main factors, there are also a number of supporting factors that influence the occurrence of violent theft with violence in the jurisdiction of the Central Java Regional Police. These supporting factors are the perpetrators' educational factors, geographical factors or the location of an area, and victims, especially women, who are mostly targeted by the perpetrators. Mitigation efforts that have been carried out by the Central Java Regional Police to reduce the crime of theft by violence are in the form of pre-emptive, preventive and repressive efforts. This effort is expected to reduce and give a deterrent effect to the perpetrators of crime, so as to provide a sense of security to the community. In reducing the crime rate of theft with violence, they must have the support of all parties, especially the public and law enforcement officers.

In advising the law enforcement, especially for perpetrators of theft by violence, is expected to be processed in accordance with applicable law and the application of severe sanctions, so that perpetrators do not repeat their actions. It is desirable for the police and other law enforcers to be consistent with the existing rules. 


\section{REFERENCES}

Mangunhardjana, A. (1986). Pembinaan: Arti dan Metodenya. Yogyakarta: Kanisius

Miles, M.B., \& Huberman, A.M. (1992). Analisis Data Kualitatif (Buku Sumber Tentang Metode-Metode baru). Jakarta: UI Pres.

Moeljatno, M. (2000). Asas-asas Hukum Pidana. Jakarta: Rineka Cipta.

Moleong, J. L. (1988). Metodologi Penelitian Kualitatif. Bandung: Remaja Rosdakarya

Moleong, L.J. 2007. Metode Penelitian Kualitatif. Bandung: Remaja Rosdakarya.

Muladi, M. (1998). Teori-teori dan Kebijakan Pidana. Bandung: P.T Alumni.

Packer. H.L. (1968). The limits of the criminal sanction. California: Stanford University Press.

Prodjohamidjojo, M. (1997). Memahami Dasar-Dasar Hukum Pidana II. Jakarta: Pradnya Paramita.

Rachman, M. (1993). Strategi dan Langkah-Langkah Penelitian. Semarang: IKIP Semarang Press.

Sahetapy, J.E. (1997). Viktimologi Sebuah Bunga Rampai. Jakarta: Pustaka Sinar Harapan. Saleh, R. (1983). Perbuatan Pidana dan Pertanggungjawaban Pidana. Jakarta: Aksara Baru. Susanto, S.I. (2011). Kriminologi. Yogyakarta: Genta Publishing. 